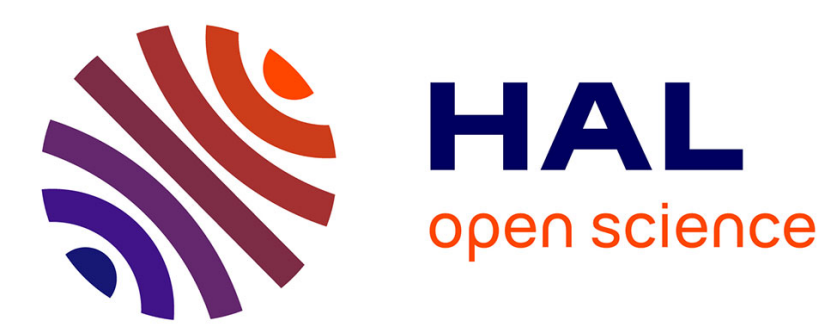

\title{
Effects of Carbon Content and Cold Working on Damping Capacity and Mechanical Property of Fe-17wt.\%Mn Martensitic Alloy
}

\author{
S. Baik, J. Kim, K. Jee, M. Shin, C. Choi
}

\section{- To cite this version:}

S. Baik, J. Kim, K. Jee, M. Shin, C. Choi. Effects of Carbon Content and Cold Working on Damping Capacity and Mechanical Property of Fe-17wt.\%Mn Martensitic Alloy. Journal de Physique IV Proceedings, 1995, 05 (C8), pp.C8-391-C8-396. 10.1051/jp4:1995858 . jpa-00254107

\section{HAL Id: jpa-00254107 https://hal.science/jpa-00254107}

Submitted on 1 Jan 1995

HAL is a multi-disciplinary open access archive for the deposit and dissemination of scientific research documents, whether they are published or not. The documents may come from teaching and research institutions in France or abroad, or from public or private research centers.
L'archive ouverte pluridisciplinaire HAL, est destinée au dépôt et à la diffusion de documents scientifiques de niveau recherche, publiés ou non, émanant des établissements d'enseignement et de recherche français ou étrangers, des laboratoires publics ou privés. 


\title{
Effects of Carbon Content and Cold Working on Damping Capacity and Mechanical Property of Fe-17wt.\%Mn Martensitic Alloy
}

\author{
S.B. Baik, J.C. Kim, K.K. Jee*, M.C. Shin* and C.S. Choi** \\ Woojin OSK Corp., Research Institute of Measuring Technology, C.P.O. Box 6666, Seoul, Korea \\ * Korea Institute of Science and Technology, Division of Metals, Seoul 136-701, Korea \\ ** Yonsei University, Department of Metallurgical Engineering, Seoul 120-749, Korea
}

\begin{abstract}
Effect of carbon content on damping capacity of $\mathrm{Fe}-17 \% \mathrm{Mn}$ alloy is investigated by varying the carbon content from $0.02 \mathrm{wt} \%$ to $0.28 \mathrm{wt} \%$. And cold rolling is conducted to examine its influence on damping capacity and mechanical properties in an $\mathrm{Fe}-17 \% \mathrm{Mn}-0.02 \% \mathrm{C}$ alloy.

With the increase in carbon content, damping capacity decreases due to the area reduction of $\gamma / \varepsilon$ boundaries and their mobility. Cold rolling up to $10 \%$ is found to improve strength as well as damping capacity in an $\mathrm{Fe}-17 \% \mathrm{Mn}-0.02 \% \mathrm{C}$ alloy without significant decrease in elongation. $\mathrm{Fe}-17 \% \mathrm{Mn}-\mathrm{X} \% \mathrm{C}$ alloy system containing carbon below about $0.1 \mathrm{wt} \%$, exhibiting superior mechanical properties and good damping capacities at high strain amplitudes, can preferably be applied as structural materials subjected to high amplitude vibration.
\end{abstract}

\section{INTRODUCTION}

In previous study ${ }^{(1,2)}$ we have shown that an $\mathrm{Fe}^{-17} \mathrm{wt} \% \mathrm{Mn}$ alloy exhibits the highest damping capacity in Fe-Mn binary system. The alloy has advantages of good mechanical properties and low cost over non-ferrous damping alloys such as $\mathrm{Mn}-\mathrm{Cu}^{[3,4]}$ and $\mathrm{Ni}^{-} \mathrm{Ti}^{[5]}$.

In commercial fabrication process, however, introduction of impurities such as carbon and nitrogen is unavoidable. But the effect of the impurities on damping capacity has not been clarified yet in the alloy.

In this study, the effect of carbon content on damping capacity is investigated by varying the carbon content from $0.02 \mathrm{wt} \%$ to $0.28 \mathrm{wt} \%$. In addition, cold rolling is carried out in an attempt to improve damping capacity and mechanical properties. 


\section{EXPERIMENTAL PROCEDURE}

The alloys were melted in air by means of a high frequency induction furnace using pure electrolytic iron and manganese with addition of recarburizer. The melts were cast into a metallic mould and the ingots were homogenized at $1150^{\circ} \mathrm{C}$ for $24 \mathrm{hrs}$, followed by hot rolling to bars and plates. After solution treatment at $1050^{\circ} \mathrm{C}$ for $1 \mathrm{hr}$, the specimens were quenched into water. The analyzed compositions of alloys used in this study are listed in Table 1.

Damping capacity was measured using Föppl-Pertz type torsional pendulum ${ }^{[6]}$, and evaluated as specific damping capacity (SDC). Transformation temperatures such as $\mathrm{Ms}$, As and Af were determined using a thermomechanical analyzer, based on the volume contraction accompanying $\gamma \rightarrow \varepsilon$ transformation. Volume fraction of $\varepsilon$ and $\alpha^{\prime}$ martensites was calculated ${ }^{[7,8]}$ by comparing integrated intensities of $(200) \gamma,(10 \cdot 1) \varepsilon$ and $(110) \alpha^{\prime}$ peaks in X-ray diffraction chart. The specimens for TEM were prepared by electropolishing with twin-jet in $10 \%$ $\mathrm{HClO}_{4} /$ methanol solution. The electron microscope used was Philips $\mathrm{CM}-30$ with an accelerating voltage of $300 \mathrm{kV}$.

Table 1. Chemical composition of the alloys used.(wt.\%)

\begin{tabular}{|c|c|c|c|c|c|c|c|c|c|c|}
\hline Alloy No. & 1 & 2 & 3 & 4 & 5 & 6 & 7 & 8 & 9 & 10 \\
\hline $\mathrm{Mn}$ & 17.68 & 17.40 & 17.84 & 17.38 & 17.86 & 17.32 & 17.88 & 17.81 & 17.56 & 17.28 \\
\hline $\mathrm{C}$ & 0.02 & 0.03 & 0.04 & 0.06 & 0.08 & 0.10 & 0.12 & 0.15 & 0.20 & 0.28 \\
\hline $\mathrm{Fe}$ & bal. & bal. & bal. & bal. & bal. & bal. & bal. & bal. & bal. & bal. \\
\hline
\end{tabular}

\section{RESULTS AND DISCUSSION}

Fig. 1 shows strain amplitude dependence of damping capacity of some $\mathrm{Fe}-17 \% \mathrm{Mn}-\mathrm{X} \% \mathrm{C}$ alloys. Damping capacities of all the alloys, irrespective of carbon content, increase steeply with strain magnitude, as is shown in Fig. 1, indicating that the alloys exhibit similar damping mechanism to that of twin-type damping alloys ${ }^{[9]}$.

Fig. 2 shows the effect of carbon content on damping capacity at $\gamma_{\max }$ of $7 \times 10^{-4}$ in the $\mathrm{Fe}-17 \% \mathrm{Mn}-\mathrm{X} \% \mathrm{C}$ alloys. As the carbon content increases, the damping capacities of $\mathrm{Fe}-17 \% \mathrm{Mn}-\mathrm{X} \% \mathrm{C}$ alloys are kept almost constant below about $0.1 \mathrm{wt} \% \mathrm{C}$, showing steep decrease on further carbon contents.

Optical microstructures of the alloys in Fig. 3 suggests that the volume fraction of $\varepsilon$ martensite decreases with increasing carbon content. In the $\mathrm{Fe}-17 \% \mathrm{Mn}-0.28 \% \mathrm{C}$ alloy, no $\varepsilon$ martensite plates are observed.

The volume fractions of each phase contained in the microstructures were determined by $\mathrm{X}$-ray diffraction method referred in the experimental procedure, and were plotted against carbon content in Fig. 4. As shown in Fig. 4, the amount of $\gamma$ austenite increases linearly with carbon content, contrary the amount of $\varepsilon$ martensite decreases abruptly up to $0.05 \mathrm{wt} \% \mathrm{C}$, showing gradual decrease on further carbon conetnt. On the other hand, the amount of $a^{\prime}$ martensite increases with carbon content, reaching a maximum value around $0.05 \mathrm{wt} \% \mathrm{C}$, and decreases on further carbon content. 


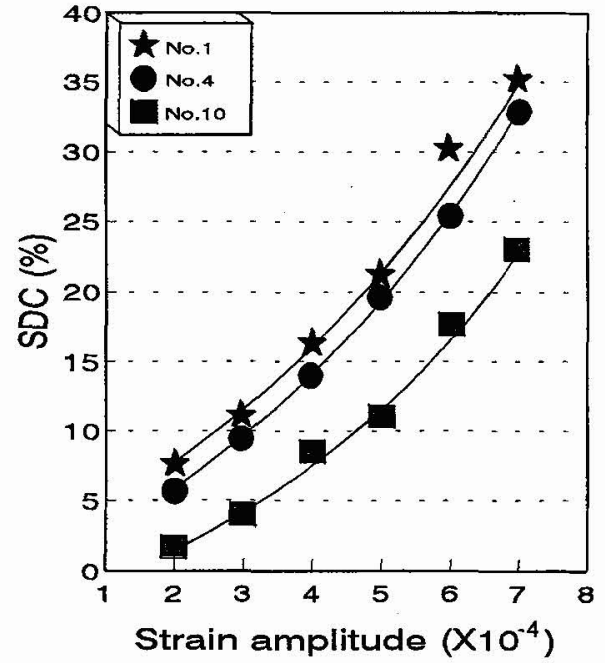

Figure 1. Variation of specific damping capacity with strain amplitude in $\mathrm{Fe}-17 \% \mathrm{Mn}-\mathrm{X} \% \mathrm{C}$ alloys.

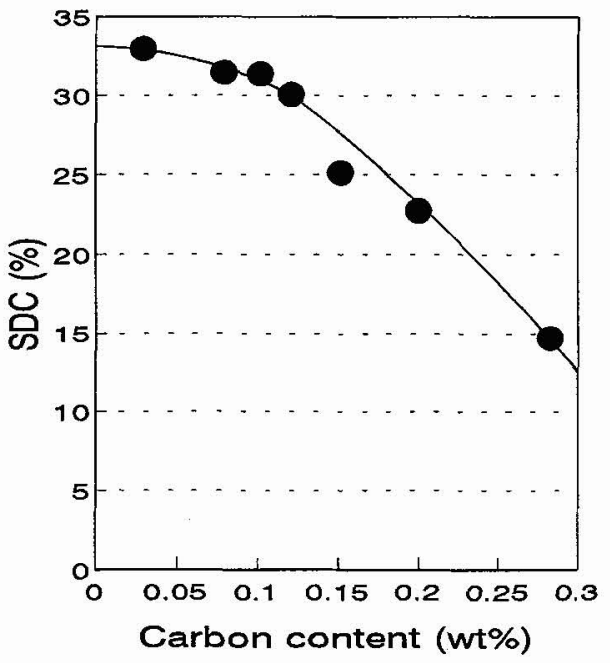

Figure 2. Variation of specific damping capacity with carbon content in $\mathrm{Fe}-17 \% \mathrm{Mn}-\mathrm{X} \% \mathrm{C}$ alloys.
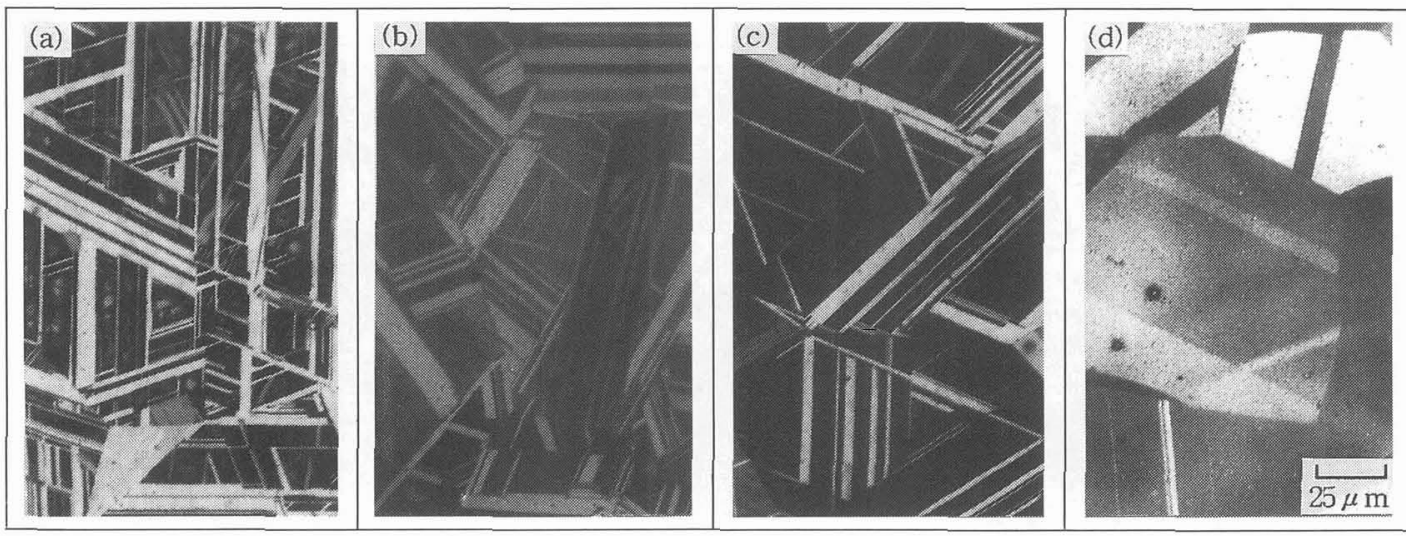

Figure 3. Microstructures of the water-quenched alloys.
(a) alloy 1
(b) alloy 6
(c) alloy 9
(d) alloy 10

Fig. 5 shows the variations transformation temperatures of $r$ to $\varepsilon$ with carbon conetnt. The $\mathrm{M}_{\mathrm{s}}$ temperature decreases with increasing carbon content. The decrease in $\varepsilon$ martensite content with carbon content in Fig. 4 is in good agreement with the variation of $M_{s}$ with carbon content shown in Fig. 5.

Fig. 6 shows transmission electron micrographs of the three alloys with different carbon contents. The $\mathrm{Fe}-17 \% \mathrm{Mn}-0.02 \% \mathrm{C}$ alloy consists of $r$ and $\varepsilon$ martensite. In the $\mathrm{Fe}-17 \% \mathrm{Mn}-0.1 \% \mathrm{C}$ alloy, smaller amount of $\varepsilon$ martensite is observed with the formation of stacking faults. With further increase in carbon content, as shown in Fig, 6(c), tiny stacking faults and only a little $\varepsilon$ martensite are observed. However, no carbides are formed due to rapid cooling in all the alloys. 


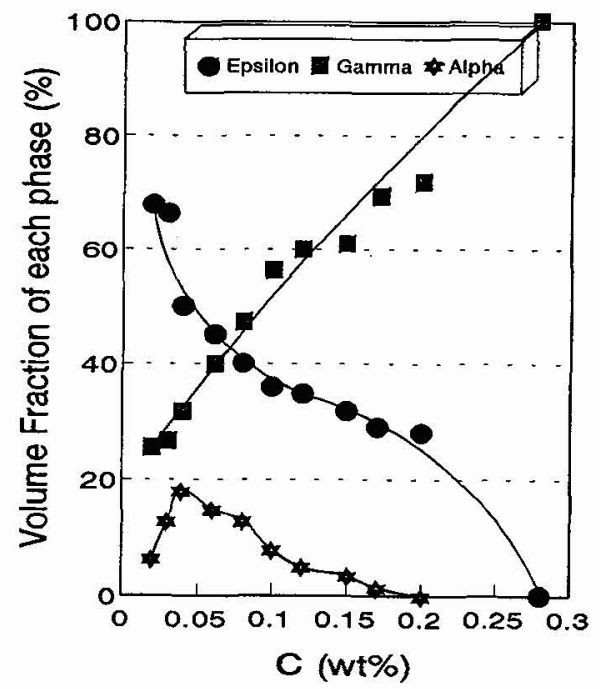

Figure 4. Variation in volume fraction of each phase with carbon content in $\mathrm{Fe}-17 \% \mathrm{Mn}-\mathrm{X} \% \mathrm{C}$ alloys.

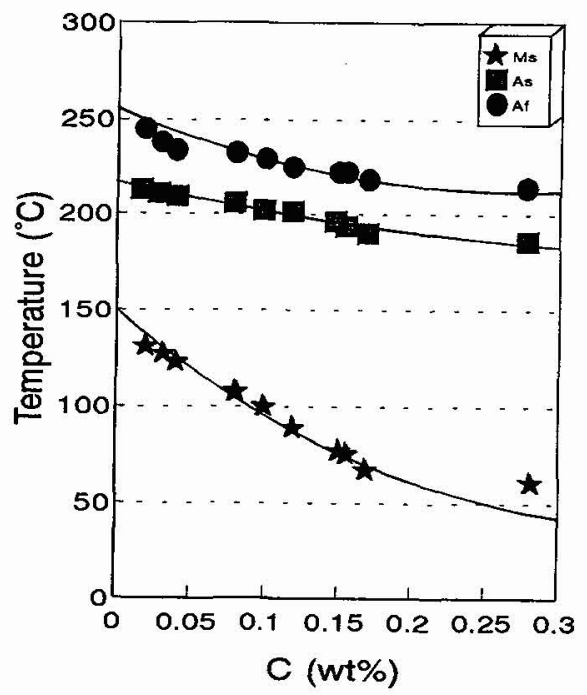

Figure 5. Variation of transformation temperatures with carbon content in $\mathrm{Fe}-17 \% \mathrm{Mn}-\mathrm{X} \% \mathrm{C}$ alloys.

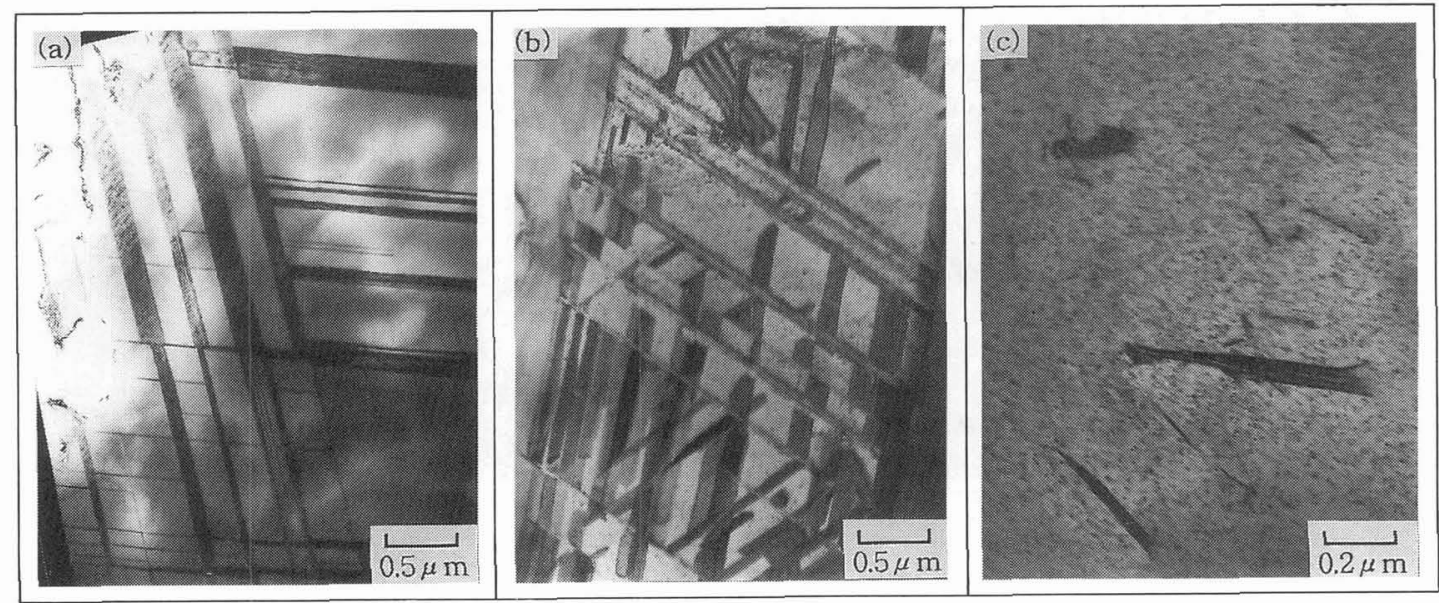

Figure 6. Transmission Electron Micrographs of the water-quenched alloys.
(a) alloy 1
(b) alloy 6
(c) alloy 10

In the previous paper ${ }^{[1,2]}$, it has been already proposed that the movement of $\gamma / \varepsilon$ interphase boundaries may be mainly responsible for damping of Fe-Mn binary alloys.

Therefore, the deterioration of damping capacity by carbon addition in Fig. 2 is attributed to the following two reasons; Firstly, as carbon content increases, the volume fraction of $\varepsilon$ martensite decreases, leading to the area reduction of $\gamma / \varepsilon$ boundaries. Secondly, carbon atoms hinder the movement of the $\gamma / \varepsilon$ boundaries by pinning them.

Fig. 7 shows the effect of cold rolling on damping capacity in the $\mathrm{Fe}-17 \% \mathrm{Mn}-\mathrm{X} \% \mathrm{C}$ alloys. All the alloys, except for the $\mathrm{Fe}-17 \% \mathrm{Mn}-0.28 \% \mathrm{C}$ alloy, experience an increase in damping capacity 
up to $10 \%$ rolling, which may be ascribed to the increase in area of $\gamma / \varepsilon$ boundaries due to formation of stress-induced $\varepsilon$ martensite. With further cold rolling, however, dislocations are generated to make the boundary movement more difficult, aggravating damping capacity.

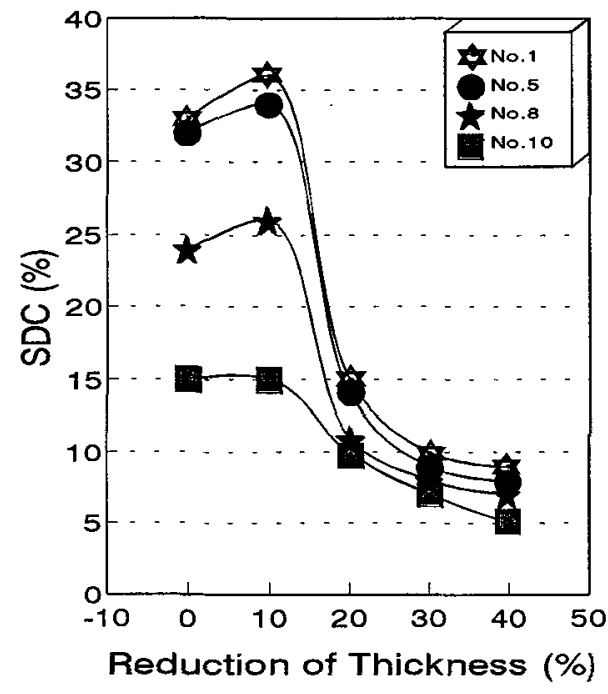

Figure 7. Variation of the specific danping capacity with rectuction of thickness in $\mathrm{Fe}-17 \% \mathrm{Mn}-\mathrm{X} \% \mathrm{C}$ alloys.

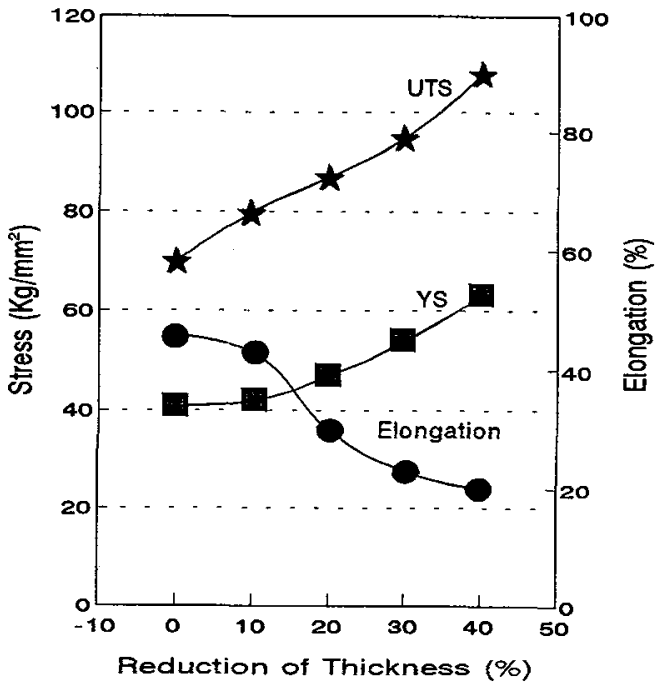

Figure 8. Variation of the mechanical properties with reduction of thickness in $\mathrm{Fe}-17 \% \mathrm{Mn}-0.02 \% \mathrm{C}$ alloy.

Mechanical properties are also changed with cold rolling, as shown in Fig. 8. Cold rolling increases strength (UTS and YS) but decreases elongation.

Considering the improvement in damping capacity and strength, though there is a little drop in elongation, $10 \%$ cold rolling is proposed as the best production condition of the $\mathrm{Fe}-17 \% \mathrm{Mn}-0.02 \% \mathrm{C}$ alloy.

\section{CONCLUSION}

(1) As the carbon content increased, the damping capacities of $\mathrm{Fe}-17 \% \mathrm{Mn}-\mathrm{X} \% \mathrm{C}$ alloys were kept almost constant below about $0.1 \mathrm{wt} \% \mathrm{C}$, showing steep decrease on further carbon contents.

(2) The damping capacities of all the $\mathrm{Fe}-17 \% \mathrm{Mn}-\mathrm{X} \% \mathrm{C}$ alloys, irrespective of carbon content, increased steeply with increasing strain magnitude.

(3) Cold rolling of about $10 \%$ improved strength as well as damping capacity in the $\mathrm{Fe}-17 \% \mathrm{Mn}-0.02 \% \mathrm{C}$ alloy without significant decrease in elongation.

\section{ACKNOWLEDGMENT}

We express our sincere thanks to president S.B.Lee of WOOJIN OSK CORP. for the financial support of this work. 


\section{REFERENCES}

[1] C. S. Choi and S. H. Baik : Proc. Int. Conf. on Martensitic Transformation, 1992, 509-514

[2] C. S. Choi and WOOJIN OSK CORP. : Koera Pat., No.057437(1992), U.S. Pat., No.5290372(1994)

[3] I. A. Arbuzova, V. S. Gavrilyuk and L. G. Khandros : Fiz. Metal. Metalloved., 27(1969), 1126

[4] K. Sugimoto, T. Mori, K. Otsuka and K. Shimiz : Scripta Met., 8(1974), 1341

[5] R. Hashiguti and K. Iwasaki : J. Appl. Phys., 39(1968), 2182

[6] A. W. Cochardt : Trans. AIME, 226(1956), 1295

[7] B. L. Averbach and M. Cohen : Trans. Met. Soc., AIME, 176(1948), 401

[8] J. Burke and D. W. Harvey : ISIJ, 208(1970), 779

[9] V. A. Teplov, V. A. Palov and K. A. Malyshev : Fiz. Metal. Metalloved., 27, No.2, 339 342, 1969 